\title{
Sistem Komputerisasi untuk Pencatatan Laporan Asuhan Keperawatan untuk Mahasiswa Ilmu Keperawatan
}

\author{
A Computer-Based Reporting System \\ for Nursing Care Plan for Nursing Students \\ Novan Aries Tuharea1*1, Darpianto Sampe Payung'2 I Gede Purnawinadi ${ }^{3}$, \\ Reymon Rotikan ${ }^{4}$ \\ ${ }^{1,2,3}$ Sistem Informasi, Fakultas Ilmu Komputer UNKLAB, \\ ${ }^{4}$ Imu Keperawatan, Fakultas Ilmu Keperawatan UNKLAB \\ E-mail: *1'novanaries@gmail.com, ${ }^{2}$ darpianto_sampepayung@yahoo.com, \\ 33urnawinadi87@unklab.ac.id, ${ }^{4}$ reymonr@unklab.ac.id
}

\begin{abstract}
Abstrak
Proses keperawatan tidak terlepas dari peran seorang perawat dalam menjalankan tugas dan tanggungjawabnya dalam memberikan layanan kesehatan terhadap pasien. Salah satu hal yang penting dalam proses keperawatan adalah membuat dokumentasi. Hal ini menjadi penting oleh karena dokumentasi asuhan keperawatan atau proses keperawatan merupakan dokumen yang mencatat tindakan yang dilakukan oleh perawat terhadap pasien. Namun dengan beban kerja yang cukup tinggi membuat banyak perawat tidak dapat menyusun dokumentasi asuhan keperawatan dengan baik. Penelitian ini bertujuan untuk membuat sebuah metode pencatatan asuhan keperawatan dengan memanfaatkan teknologi informasi dengan membuat sebuah aplikasi komputer. Adapun dalam penelitian ini menggunakan mahasiswa Fakultas Ilmu Keperawatan, Universitas Klabat sebagai objek penelitian, dengan pertimbangan kemudahan dalam melakukan observasi dan wawancara untuk mengetahui kebutuhan dalam pengembangan aplikasi. Aplikasi yang dikembangkan mengikuti standar asuhan keperawatan dari NANDAInternational. Adapun hasil penelitian menunjukkan penggunaan aplikasi dalam membuat dokumentasi dan laporan asuhan keperawatan memberikan kemudahan bagi mahasiswa, dimana dapat mempersingkat waktu penyusunan laporan. Dan walaupun penelitian ini menggunakan mahasiswa sebagai objek penelitian, namun hasil penelitian juga dapat digunakan oleh perawat yang bekerja di Rumah Sakit.
\end{abstract}

Kata Kunci — laporan, asuhan keperawatan, sistem terkomputerisasi

\begin{abstract}
The nursing process is inseparable from the role of a nurse in carrying out its duties and responsibilities in providing health services to patients. One of the things that are important in the nursing process is to make the documentation or the nursing care plan. This is important because this documentation is a document that records the actions taken by nurses to patients. However, the workload is high enough for a nurse to be able to make the documentation. Therefore, in this study an attempt has been made to create a reporting tools for nursing care plan by utilizing information technology with creating a computer application. As in this study, the students at the Faculty of Nursing, Universitas Klabat are becoming the research object, with consideration of ease of observation and interviews to assess the needs in application development. The developed application follows the standards of nursing care documentation of NANDA-International. The research results indicate, that the use of applications in creating nursing care plan report provides convenience for students, which can shorten the time of preparation of the report. And although in this study using nursing students as research the object, but the computer application can also be used by nurses who are working at the hospital.
\end{abstract}

Keywords - reporting, nursing care plan, computer-based system 


\section{PENDAHULUAN}

Memberikan layanan kesehatan yang layak dan baik kepada masyarakat merupakan salah satu tanggung jawab dari sebuah institusi atau lembaga kesehatan baik Rumah Sakit, Pusat Kesehatan Masyarakat (Puskesmas), atau lembaga lainnya. Salah satu proses yang penting dalam memberikan layanan kesehatan adalah perawatan terhadap pasien. Perawatan pasien merupakan suatu proses atau rangkaian kegiatan yang diberikan secara langsung dengan metode yang ilmiah, sistematis, dinamis, dan terus-menerus serta berkesinambungan dalam rangka pemecahan masalah kesehatan pasien, dimulai dari pengkajian (pengumpulan data, analisis data, dan penentuan masalah) diagnosis keperawatan, pelaksanaan, dan penilaian tindakan keperawatan [1]. Dalam pelaksanaan asuhan keperawatan pada pasien, salah satu hal yang penting untuk dilakukan adalah membuat dokumentasi asuhan keperawatan. Dokumentasi ini berisi hasil aktivitas keperawatan yang dilakukan perawat terhadap pasien, mulai dari pengkajian hingga evaluasi, sehingga dokumentasi asuhan keperawatan menjadi bukti tindakan keperawatan yang telah dilakukan oleh perawat kepada pasien [2]. Dokumentasi asuhan keperawatan juga dapat dijadikan sarana komunikasi dari satu profesi ke profesi lain terkait status seorang pasien, bahkan sewaktuwaktu dapat dijadikan sebagai barang bukti di pengadilan jika ada gugatan yang dilayangkan oleh pasien atau keluarganya. Melihat pentingnya dokumentasi asuhan keperawatan, pembuatan dokumentasi ini haruslah dilakukan dengan baik dan terstruktur.

Pembuatan dokumentasi asuhan keperawatan dilakukan oleh seorang perawat. Dibutuhkan ketelitian dan penulisan informasi yang lengkap dan detail terkait tindakan keperawatan yang telah dilakukan. Beberapa hasil penelitian menunjukkan bahwa masih ada banyak permasalahan terkait pembuatan dokumentasi asuhan keperawatan. Faktor yang membuat pelaksanaan dokumentasi asuhan keperawatan belum lengkap adalah pelatihan dan beban kerja, hasil penelitian menunjukkan bahwa ada hubungan antara masa kerja, pelatihan dan beban kerja dengan kelengkapan dokumentasi [3]. Selain itu motivasi juga turut berkontribusi dalam mendorong seorang perawat untuk melaksanakan dokumentasi asuhan keperawatan [4][5]. Penelitian lain menunjukkan bahwa supervisi dari kepala ruangan juga diperlukan karena dapat meningkatkan kinerja perawat dalam membuat dokumentasi asuhan keperawatan yang lengkap [6]. Semua faktor diatas berkaitan dengan perawat yang telah bekerja, hal ini tentunya menjadi perhatian bagi penyelenggara pendidikan tinggi, khususnya yang menyediakan program studi Ilmu Keperawatan. Ini tentunya menjadi tantangan tersendiri untuk menghasilkan lulusan yang terlatih dengan baik, memiliki motivasi tinggi untuk menjadi seorang perawat dalam melaksanakan tugas dan tanggung jawabnya.

Saat ini di level Universitas yang memiliki program studi Ilmu Keperawatan, semuanya mengajarkan mahasiswa untuk membuat dokumentasi asuhan keperawatan. Tentu hal ini sangatlah baik, oleh karena mahasiswa dapat dilatih membuat laporan yang baik. Namun masih ada beberapa permasalahan yang dihadapi, antara lain adalah, pembuatan dokumentasi asuhan keperawatan dilakukan secara manual dengan mencatat menggunakan pulpen atau pensil dan buku. Pencatatan yang dilakukan secara manual membuat mahasiswa hanya fokus dalam membuat pencatatan dibandingkan memperhatikan proses perawatan yang dilakukan pada pasien. Selain itu tenggat waktu pembuatan dokumentasi yang singkat dan jumlah laporan yang harus disusun cukup banyak, membuat mahasiswa menyusun dokumentasi asuhan keperawatan dengan terburu-buru, sehingga laporan yang dibuat tidak lengkap, atau tidak sesuai dengan standar yang digunakan.

Melihat permasalahan yang dihadapi oleh mahasiswa dalam melaksanakan proses keperawatan, khususnya dalam membuat laporan dokumentasi asuhan keperawatan, menjadi latar belakang permasalahan yang diangkat. Penelitian ini bertujuan untuk membuat sebuah metode pencatatan dan penyusunan laporan dokumentasi asuhan keperawatan untuk mahasiswa ilmu keperawatan. 


\subsection{Tinjauan Literatur}

\subsubsection{Proses Keperawatan}

Proses keperawatan memiliki pengertian sebagai suatu bentuk layanan kesehatan professional yang merupakan bagian integral dari layanan kesehatan yang dilandaskan pada ilmu dan kiat keperawatan dalam bentuk layanan bio, psiko, sosial, dan spiritual yang komprehensif dan ditujukan untuk individu, keluarga, dan masyarakat, baik dalam keadaan sehat ataupun sakit dan mencakup seluruh proses kehidupan [7]. Sebagai metode ilmiah, proses keperawatan terdiri dari beberapa tahap yaitu, tahap pengkajian, diagnosis, perencanaan, implementasi, dan evaluasi. Gambar 1[2] memperlihatkan tahapan dalam proses keperawatan. Suatu proses keperawatan juga memiliki beberapa karakteristik, yaitu [8]:

1. Tujuan. Supaya suatu proses dapat tercapai, maka setiap langkah harus memiliki tujuan yang jelas dan spesifik beserta indikator-indikatornya.

2. Sistematik. Proses keperawatan dalam pemecahan masalah menggunakan tahapan-tahapan sistematis yang meliputi: pengkajian, diagnosis keperawatan, perencanaan, pelaksanaan, dan evaluasi.

3. Dinamis. Masalah yang terjadi dapat berubah dan dinamis, sesuai dengan situasi dan kondisi klien. Oleh karena itu, perlu penyesuaian dalam usaha pemecahan masalah yang ada.

4. Interaktif. Tahapan dalam proses keperawatan saling berhubungan satu sama lain.

5. Fleksibel. Tahapan dalam proses keperawatan dapat berubah sesuai dengan masalah yang dihadapi saat ini.

6. Teoretis. Setiap penggunaan tahapan yang terdapat dalam proses keperawatan haruslan didukung dengan landasan teoretis, sehingga hasil yang didapatkan akan terfokus sesuai dengan masalah yang ditemukan.

7. Siklis. Evaluasi dari proses keperawatan akan memberikan umpan balik pada pengkajian berikutnya, dan terus berlanjut seperti sebuah siklus sampai masalah klien terpecahkan.

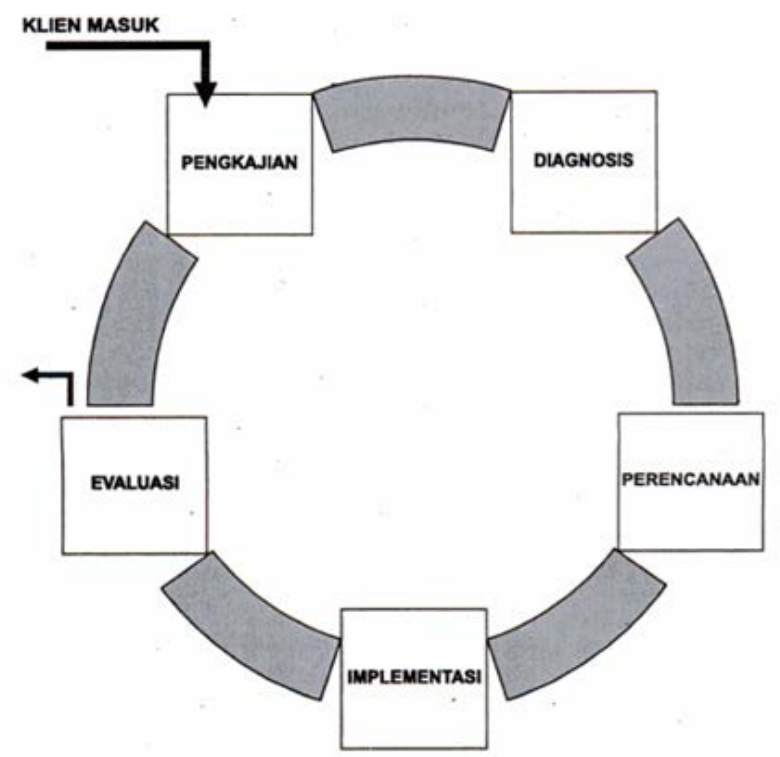

Gambar 1. Tahapan proses keperawatan 


\section{METODE PENELITIAN}

Metode penelitian yang digunakan adalah melakukan observasi dan wawancara. Observasi dilakukan terhadap kegiatan mahasiswa ilmu keperawatan dalam melaksanakan proses keperawatan dan penyusunan laporan asuhan keperawatan. Sedangkan wawancara dilakukan pada mahasiswa dan Dosen untuk mengidentifikasi permasalahan dan solusi yang diinginkan untuk membuat penyusunan laporan asuhan keperawatan yang baik. Adapun sample yang digunakan dalam penelitian ini adalah mahasiswa dan Dosen dari Fakultas Ilmu Keperawatan, Universitas Klabat, khususnya yang mengambil mata kuliah Asuhan Keperawatan. Pemilihan Universitas Klabat sebagai objek penelitian dengan mempertimbangkan kemudahan dalam mengakses setiap kegiatan yang dilakukan oleh mahasiswa.

Selain itu dalam penelitian ini juga mengadopsi metode pengembangan Rekayasa Perangkat Lunak (RPL) model Sprial. Dalam model Spiral pengembangan sebuah aplikasi dilakukan secara sistematis dan iteratif, hal ini dikarenakan sifat dari model Spiral yang merupakan gabungan antara model Waterfall dan Prototyping [9]. Hal ini memberikan keuntungan tersendiri, oleh karena pengembangan aplikasi dapat dilakukan secara dinamis namun tetap sistematis. Gambar 2 memperlihatkan tahapan dalam pengembangan aplikasi menggunakan model Spiral [7].

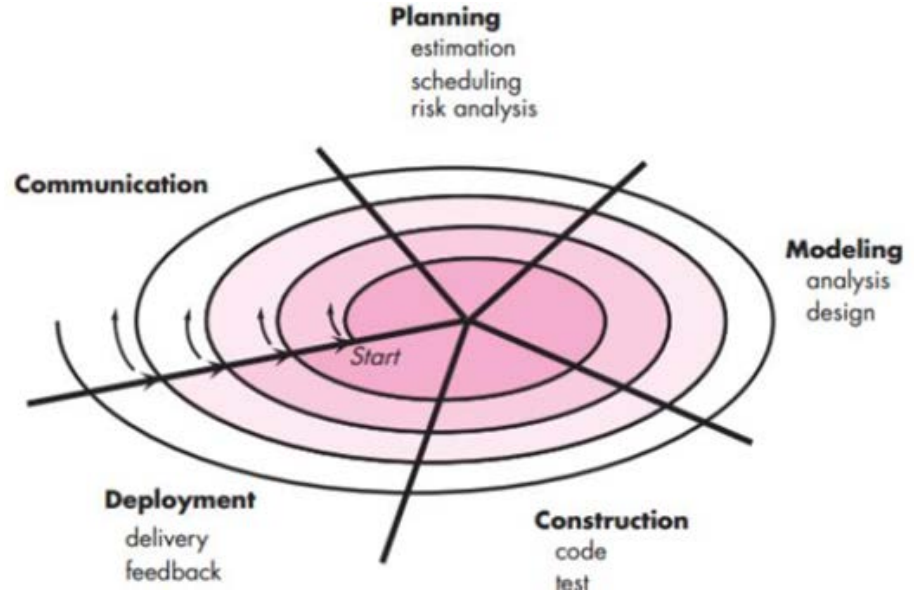

Gambar 2. Model pengembangan Spiral

\section{HASIL DAN PEMBAHASAN}

Pembahasan dibagian ini diawali dengan analisis sistem yang dibuat dengan menampilkan Use Case Diagram. Use Case Diagram merupakan bagian dari Unified Modeling Language, yaitu sebuah bahasa pemodelan sistem/aplikasi yang berorientasi pada objek dan banyak digunakan untuk membuat analisis kebutuhan pengembangan aplikasi [10]. Use Case Diagram memperlihatkan fungsionalitas yang tersedia di dalam sistem sesuai dengan kebutuhan user. Selanjutnya dijelaskan perancangan database aplikasi, setelah itu hasil implementasi dari perancangan aplikasi yang dibuat dengan menampilkan screenshot aplikasi beserta penjelasan.

\subsection{Use Case Diagram}

Gambar 3 memperlihatkan hasil analisis dalam bentuk Use Case Diagram dari aplikasi asuhan keperawatan. Dapat dilihat bahwa aplikasi asuhan keperawatan yang dibuat memiliki satu actor, yaitu Perawat, dan tujuh use case, yaitu manage data pasien, manage nursing diagnose, manage intervention, manage implementation, manage evaluation, print documentation, dan use case login. 


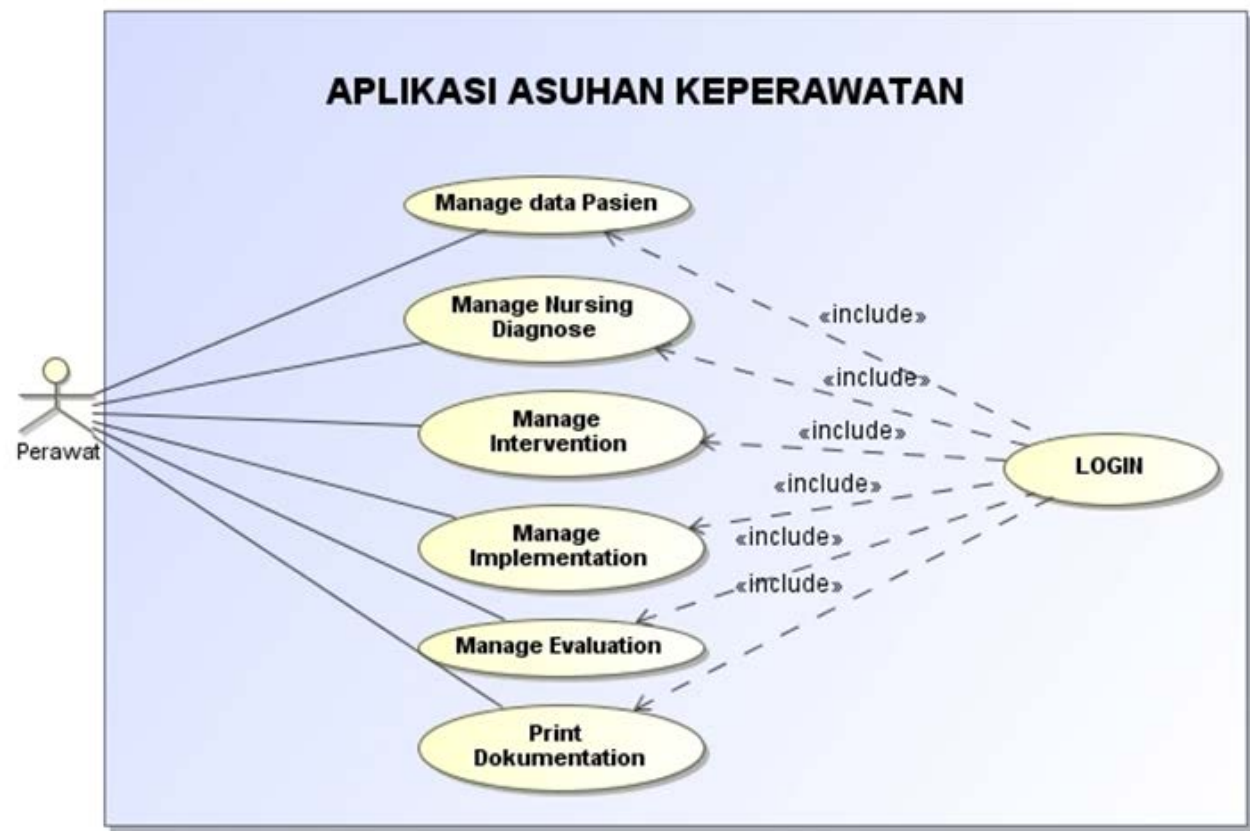

Gambar 3. Use Case Diagram aplikasi asuhan keperawatan

Actor Perawat dalam konteks penelitian ini adalah mahasiswa Fakultas Ilmu Keperawatan, Universitas Klabat. Actor Perawat memiliki akses untuk menggunakan fungsi mengatur data pasien, pada fungsi ini actor perawat dapat memasukkan biodata dari pasien yang sedang dirawat. Fungsionalitas lain yang dapat diakses oleh actor perawat adalah mengatur hasil diagnosa pasien, mengatur intervensi yang dilakukan, implementasi perawatan pada pasien, dan evaluasi tindakan yang dilakukan. Fungsi mencetak laporan asuhan keperawatan juga dapat dilakukan oleh actor perawat. Use case login digunakan untuk mengidentifikasi dan memvalidasi actor perawat untuk masuk ke dalam sistem. Adapun use case login memiliki relasi tipe include dengan use case lainnya. Ini berarti bahwa untuk dapat menggunakan semua fungsionalitas yang tersedia dalam aplikasi, seorang actor perawat haruslah tervalidasi terlebih dahulu.

\subsection{Implementasi Database}

Dalam pengembangan aplikasi di penelitian ini menggunakan Database Management System (DBMS) MySQL. Penggunaan DBMS MySQL ini banyak digunakan dikalangan akademisi maupun industri, oleh karena sifatnya yang open source, mudah digunakan, dan ketersediaan dokumentasi yang baik menjadi alasan mengapa DBMS MySQL banyak digunakan. Gambar 4 memperlihatkan hasil analisis dan implementasi database aplikasi asuhan keperawatan.

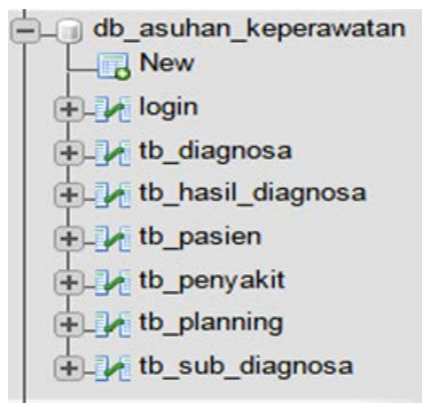

Gambar 4. Implementasi database 
Dalam implementasi database, terdapat 7 tabel yang dibuat. Tabel login dibuat untuk menyimpan data pengguna yang digunakan untuk memvalidasi user yang akan menggunakan aplikasi. User dalam aplikasi ini adalah perawat atau mahasiswa. Tabel tb_diagnosa menyimpan daftar diagnosa penyakit, dan tabel tb_hasil_diagnosa untuk menyimpan hasil diagnosa pasien. Table lainnya yaitu tb_pasien untuk menyimpan data pasien, tb_penyakit untuk menyimpan penyakit pasien. Tabel tb_planning untuk menyimpan catatan perencanaan asuhan keperawatan, dan tb_sub_diagnosa untuk jenis diagnosis berdasarkan tabel utama yaitu tb_diagnosa.

\subsection{Implementasi Sistem}

Pada bagian ini dijelaskan hasil implementasi dari analisis sistem yang telah dibuat. Adapun bagian yang dibahas adalah pengaturan data pasien, pencatatan diagnosa, dan fungsi print atau mencetak laporan asuhan keperawatan. Gambar 5 memperlihatkan tampilan form pengaturan data pasien. Form pengaturan data pasien digunakan untuk memasukkan data pasien, berupa nama pasien, umur, nomor kamar, nama Physician, dan medical diagnosis. Pengguna aplikasi (perawat/mahasiswa) dapat memasukkan sebanyak mungkin pasien yang mereka tangani. Selain itu juga disediakan fungsionalitas untuk memperbarui data pasien (update), dan menghapus data pasien (delete). Sedangkan pada Gambar 6 terlihat tampilan pencarian pasien.

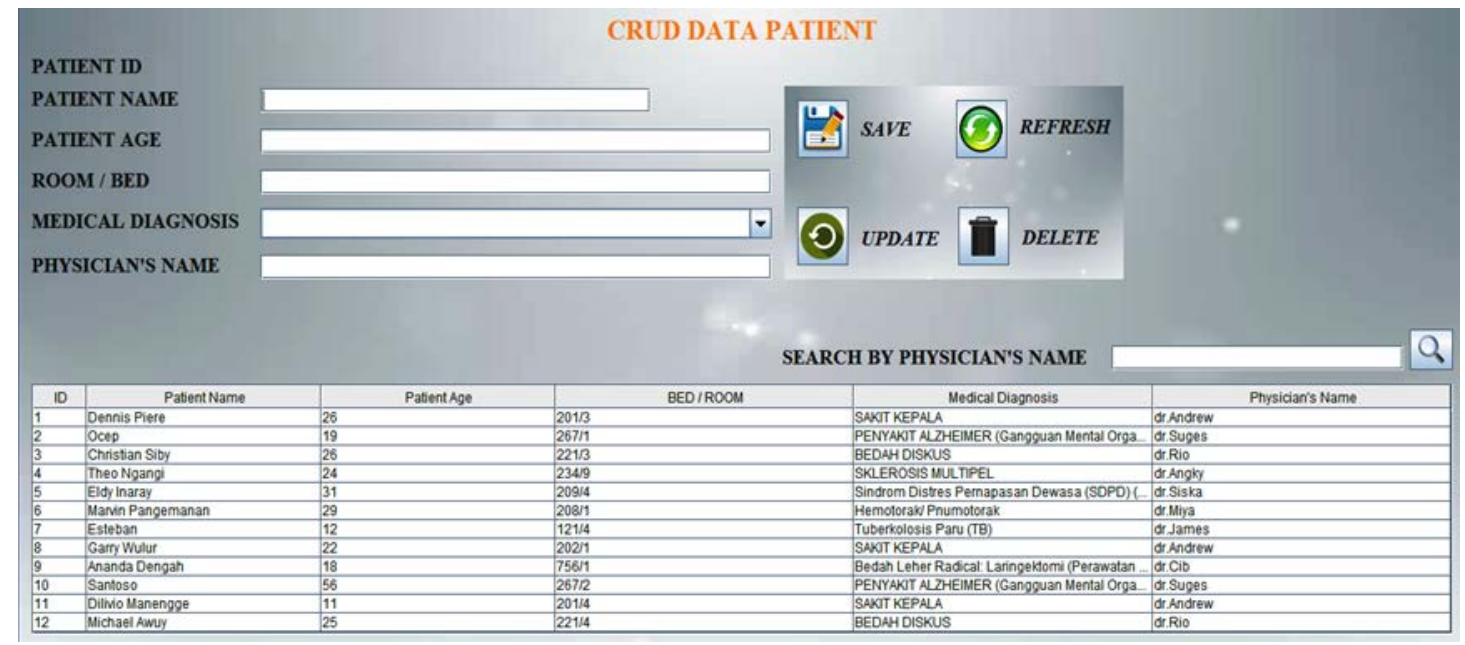

Gambar 5. Tampilan form pengaturan data pasien

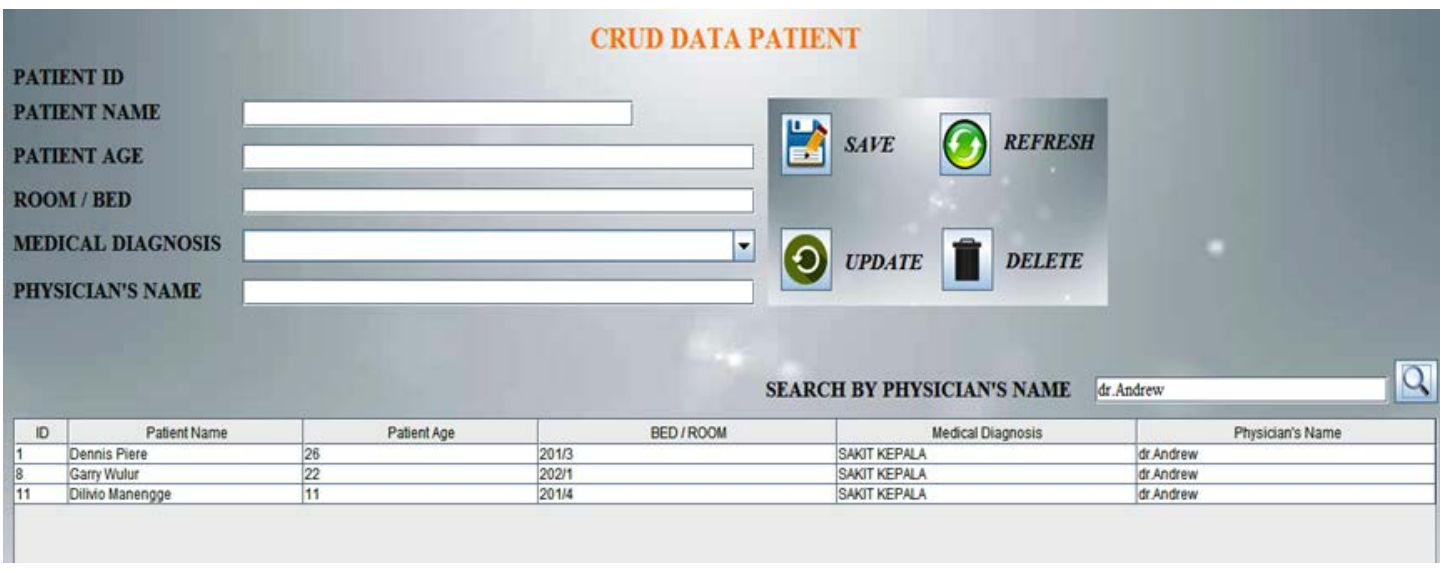

Gambar 6. Tampilan form pencarian data pasien menggunakan physician’s name

Gambar 7 menampilkan form diagnosis penyakit pasien. Pada halaman ini user (perawat/ mahasiswa) memilih pasien yang akan dilakukan pencatatan asuhan keperawatan. Setelah memilih pasien, langkah selanjutnya user memilih diagnose dari pasien tersebut. Pilihan diagnosa 
Citec Journal, Vol. 4, No. 4, Agustus 2017 - Oktober 2017

ISSN: 2460-4259

sudah disediakan, sehingga user tinggal memilih salah satu dengan cara mengklik, kemudian memilih sub diagnosa, intervention, dan tanggal pelaksanaan perawatan. Kemudian dibagian bawah yaitu Nursing Diagnosis, Goal, Interventions, Rationale, Implementations, dan Evaluation akan diisi oleh user yang dalam hal ini adalah mahasiswa. Setelah mengisi form ini dengan lengkap, user tinggal mengklik tombol Simpan dan data diagnosa dari pasien tersebut akan tersimpan.

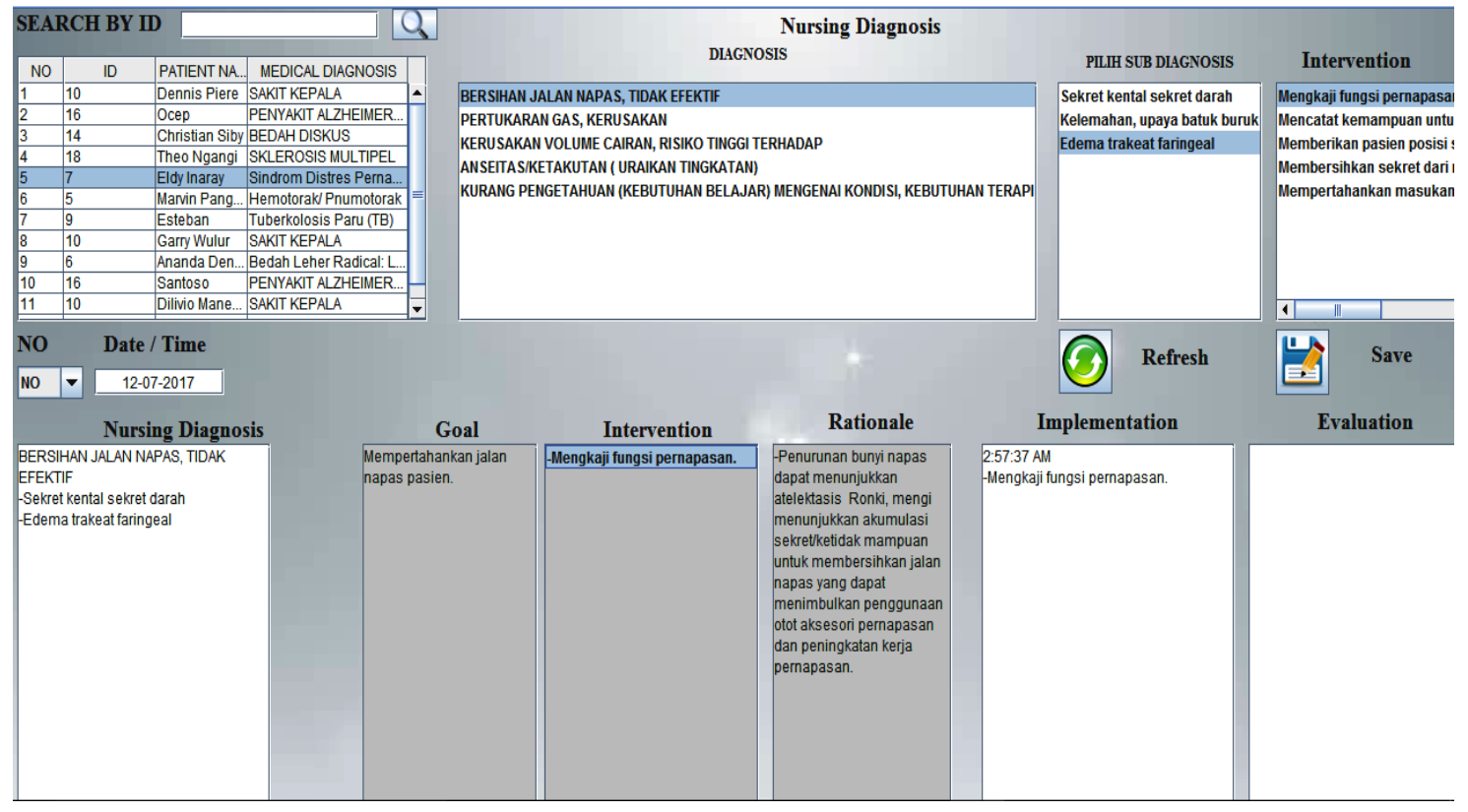

Gambar 7. Tampilan halaman Diagnosis

Kemudian pada Gambar 8 memperlihatkan tampilan halaman untuk memilih hasil diagnose yang ingin di-print atau dicetak. Pada halaman cetak ini, user tinggal memilih nama pasien untuk dicetak catatan asuhan keperawatannya. Untuk memilih pasien, user tinggal memasukkan nama pasien dan mengklik tombol Cari dengan disimbol kaca pembesar. Adapun hasil cetak dari catatan asuhan keperawatan dapat dilihat pada Gambar 9. Dan untuk menyusun laporan asuhan keperawatan secara lengkap untuk semua pasien, seorang user hanya perlu mencetak semua catatan asuhan keperawatan dari semua pasiennya, dan melakukan kompilasi untuk menyusun sebuah laporan.

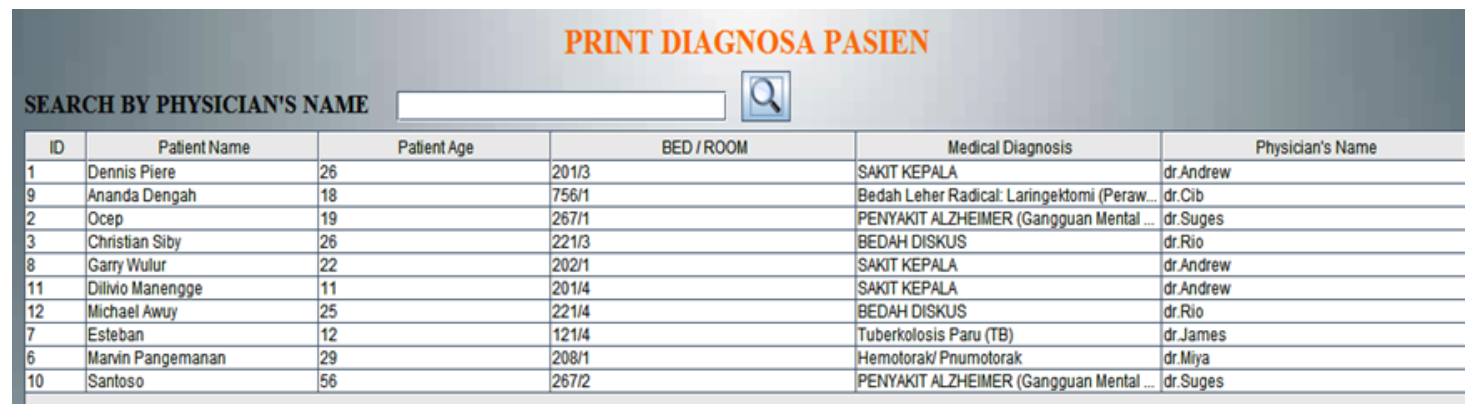

Gambar 8. Tampilan halaman untuk mencetak laporan 


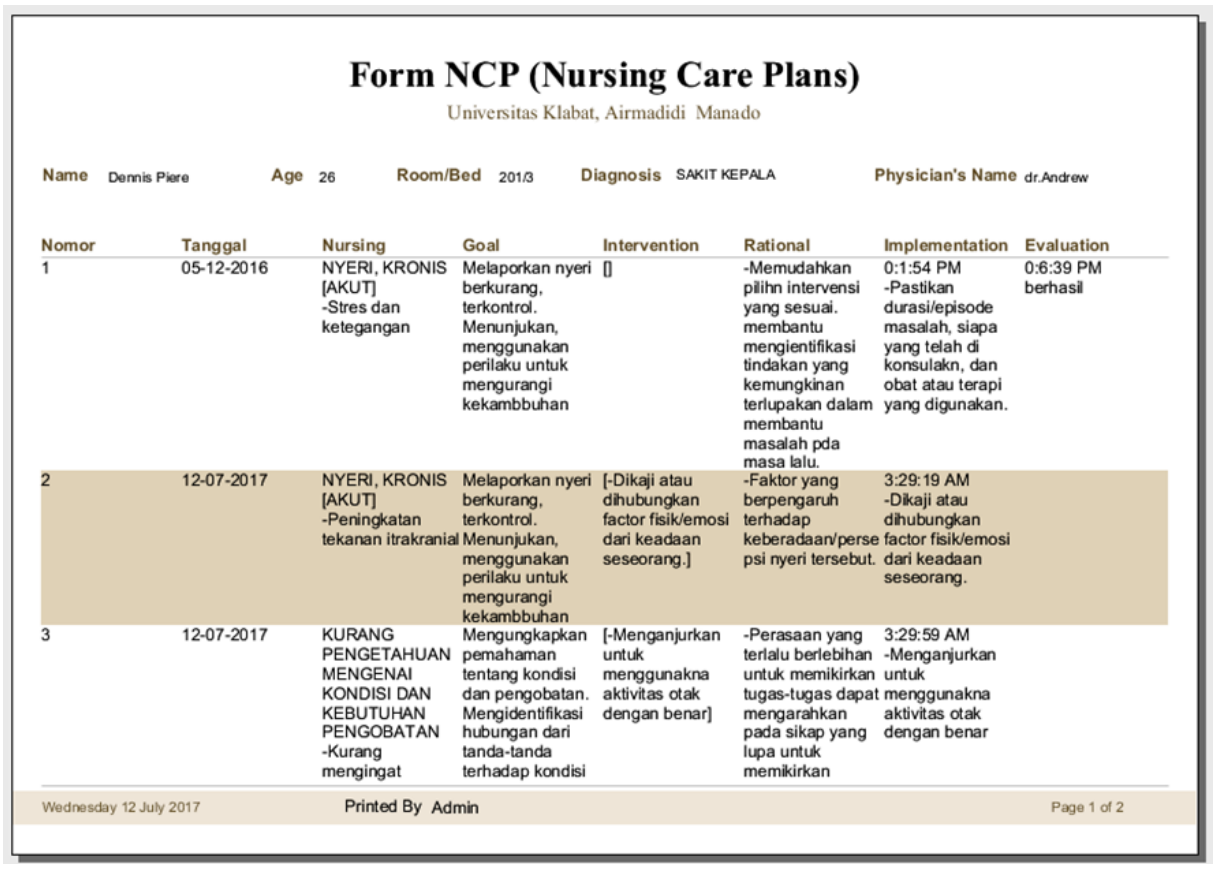

Gambar 9. Hasil cetak laporan asuhan keperawatan

\section{KESIMPULAN}

Hasil yang didapatkan dalam penelitian ini adalah sebuah aplikasi untuk membantu mahasiswa Ilmu Keperawatan dalam membuat laporan asuhan keperawatan. Adapun aplikasi yang dihasilkan masih terbatas untuk dua penyakit saja, yaitu sistem pernapasan dan saraf. Namun dari hasil uji coba penggunaan aplikasi, didapati bahwa rata-rata waktu penyusunan laporan asuhan keperawatan dapat dilakukan lebih cepat dibandingkan dengan cara manual yang selama ini digunakan oleh mahasiswa. Jika sebelumnya seorang mahasiswa membutuhkan waktu sekitar 2-3 minggu dalam menyusun laporan asuhan keperawatan berdasarkan catatan manual yang ditulis, namun menggunakan aplikasi komputer seorang mahasiswa dapat menyelesaikan laporannya dalam waktu 5-6 hari.

Namun demikian, aplikasi yang telah dibuat masih memiliki beberapa kekurangan, antara lain karena aplikasi yang dibuat adalah Desktop Application, maka proses pencatatan asuhan keperawatan masih tetap membutuhkan catatan manual terlebih dahulu dan diposting ke dalam aplikasi, aplikasi yang dibuat belum dilakukan tahap pengujian kepada calon user, yaitu mahasiswa Ilmu Keperawatan.

\section{SARAN}

Pengembangan lanjutan yang dapat dilakukan dari penelitian ini adalah dengan menambahkan lagi daftar penyakit di dalam database agar cakupan menjadi lebih luas, fungsi pencarian berdasarkan diagnosa, dan penambahan informasi dalam bentuk gambar ataupun video. 


\section{DAFTAR PUSTAKA}

[1] Ali, Z. 1997, Pengantar Keperawatan Keluarga, Penerbit Buku Kedokteran EGC, Jakarta.

[2] Asmadi, 2008, Konsep Dasar Keperawatan, Penerbit Buku Kedokteran EGC, Jakarta.

[3] Siswanto, L. M. H., Hariyati, Rr. T. S., Sukihananto, 2013, Faktor-Faktor Yang Berhubungan Dengan Kelengkapan Pendokumentasian Asuhan Keperawatan, Jurnal Keperawatan Indonesia, Vol. 16, No. 2, Hal. 77-84.

[4] Miladiyah, N., Mustikasari, Dewi. G., 2015, Hubungan Motivasi Dan Komitmen Organisasi Dengan Kinerja Perawat Dalam Pelaksanaan Dokumentasi Asuhan Keperawatan, Jurnal Keperawatan Indonesia, Vol. 18, No. 1, Hal. 9-16.

[5] Berthiana, 2013, Hubungan Motivasi Kerja Perawat Dengan Ketepatan Pengisian Dokumentasi Asuhan Keperawatan di Ruang Rawat Inap RSUD Buntok, Jurnal Managemen Keperawatan, Vol. 1, No. 1, Hal. 57-72.

[6] Dewi, R., Yetti, K., Ayubi, D., 2008, Supervisi Kepala Ruangan Berdasarkan Kelengkapan Pendokumentasian Asuhan Keperawatan, Jurnal Keperawatan Indonesia, Vol. 12, No. 3, Hal. 187 - 192.

[7] Suprajitno, 2003, Asuhan Keperawatan Keluarga: Aplikasi Dalam Praktik, Penerbit Buku Kedokteran EGC, Jakarta.

[8] Haryanto, 2007, Konsep Dasar Keperawatan Dengan Pemetaan Konsep (Concept Mapping), Penerbit Salemba Medika, Jakarta.

[9] Pressman, R. S., 2010, Software Engineering: A Practicioner's Approach 7th Edition, McGraw Hill, New York.

[10] Miles, R., Hamilton, K., 2006, Learning UML 2.0: A Pragmatic Introduction to UML, O’Reilly Media, California. 